\title{
Droplet Spectrum Produced in Pumpkin Cultures Submitted to Different Forms of Spraying
}

\author{
Edney L. da Vitória ${ }^{1}$, Deborah H. Crause ${ }^{1}$, Ismael L. de J. Freitas ${ }^{1}$, Tamara Locatelli ${ }^{2}$, Elcio das G. Lacerda ${ }^{3}$, \\ Juliana M. Valle ${ }^{1}$, Marcelo B. da Silva ${ }^{1}$, Adriano A. Fernandes ${ }^{1}$, Rafael Z. da Vitória ${ }^{1}$, Francisco de A. Ferreira ${ }^{1}$, \\ Joyce L. dos Santos ${ }^{1} \&$ Silvério de P. Freitas ${ }^{2}$ \\ ${ }^{1}$ Department of Agrarian and Biological Sciences, Federal University of Espirito Santo, São Mateus, ES, Brazil \\ ${ }^{2}$ Postgraduate in Plant Production, State University of North Fluminense, Campos, RJ, Brazil \\ ${ }^{3}$ Department of Agronomy, Federal Institute of Espírito Santo, Santa Teresa, ES, Brazil \\ Correspondence: Edney L. da Vitória, Department of Agrarian and Biological Sciences, Federal University of \\ Espírito Santo, R. Governador Mário Covas, Km 60-B, Litorâneo, São Mateus, ES, CEP 29932-540, Brazil. \\ E-mail: edney.vitoria@ufes.br
}

Received: September 18, 2018

Accepted: June 14, 2019 Online Published: August 31, 2019

doi:10.5539/jas.v11n14p56

URL: https://doi.org/10.5539/jas.v11n14p56

\begin{abstract}
The uniformity and droplet size produced during the spraying as well the correct deposition of these in the target, contribute directly to the success of a pesticide application. The objective of the present study was to characterize the ejected spray in the aerial and terrestrial spraying of pumpkin crops, with the use of adjuvants in a liquid solution. The experiment was carried out in two commercial plantations, in an entirely randomized design, employing a $6 \times 2$ factorial scheme, with six forms of application and two liquid compositions. The droplet spectrum was assessed employing water-sensitive card imaging. Smaller drop sizes and relative amplitudes were produced by aerial applications. In turn, the largest droplet diameters and the lowest percentage of drops smaller than $100 \mu \mathrm{m}$ were obtained when using air induction twin flat spray nozzles. The adjuvant did not interfere in the numerical and volumetric median diameters, the relative amplitude, or the volume rate of droplets smaller than $100 \mu \mathrm{m}$.
\end{abstract}

Keywords: spray quality, solution deposition, aerial spraying, terrestrial spraying, Cucurbita moschata

\section{Introduction}

The pumpkin (Cucurbita moschata Duch.) retains the central region of Mexico as its center of origin. It is a widely cultivated vegetable in Brazil, especially in semi-arid regions, where the climatic conditions are highly favorable for its cultivation, constituting an essential food for low-income populations (Filgueira, 2008).

The quality and quantity production of pumpkin requires the effective control of pests, diseases, and weeds, which is directly related to spraying techniques. The most employed method for the protection of pumpkin crops consists of terrestrial application using back or tractorized hydraulic sprayers. Nevertheless, the operational advantages described by aerial spraying have caused a considerable increase in this form of application, although further research is required (Bueno et al., 2011).

The method of application of phytosanitary products is essential, but, most of the time, emphasis is given mainly to the applied product and little attention to the application technique. Knowledge of the employed product is not enough. Comprehension of the technology of agricultural pesticide application is fundamental. Furthermore, it is necessary to ensure that the product reaches its target efficiently, minimizing losses (Cunha et al., 2010).

Ensuring that spray droplets exhibit uniform distribution and homogeneous sizes is a major factor which can interfere with the quality of agricultural defensive applications. Therefore, during application, overall caution should be given in order to avoid the production of extremely large or small droplets (Cunha et al., 2007). Large drops generate low surface coverage and drainage; on the other hand, they are less prone to wind displacement. Small droplets, although they enable optimal target coverage, may undergo problems such as drift and evaporation, with consequent risks regarding environmental contamination (Figueiredo et al., 2007; Nuyttens et al., 2009). 
Hollow cone spray nozzles, which are similar to rotating atomizers used in agricultural aircrafts and sprinklers, are traditionally employed in the application of fungicides and insecticides, and have as a common characteristic the production, in general, of fine droplets. This attribute provides excellent coverage of the target, being, however, highly susceptible to drift. One way to reduce this problem is by using drift-reducing nozzles, or ones that produce coarse drops but provide a good coverage of the target, such as air induction twin flat spray nozzles (Bayer et al., 2011).

One of the problems described when using air induction nozzles is the fact that some commercial brands do not provide sufficient information regarding the population and the size of the produced droplets, the potential drift risk, and their volumetric distribution (Viana et al., 2010).

The addition of adjuvants to the spray mix can aid in drift reduction. Numerous types of adjuvants, which operate differently, can be found on the market, and their potential characteristics include improved wetting, spreading, adherence, and leaf penetration (Carvalho et al., 2009; Chechetto et al., 2013), as well as reduced surface tension of the droplets by enhancing leaf coverage (Cunha \& Alves, 2009; Vanzyl et al., 2010). However, Lan et al. (2007) reported that the addition of adjuvants can alter application performance, and may lead to positive or negative effects regarding product deposition on the target.

The biological efficacy of a phytosanitary treatment can be better evaluated if an analysis of the droplet population is performed following application. One of the tools employed for this assessment is the use of artificial targets, such as water-sensitive cards (Bouse et al., 1994). When properly handled, these cards are valuable tools for determining the quality of sprays, particularly in aerial rotating atomizer applications, which do not allow for easy laboratory assessments of the drop spectrum, employing laser droplet analysis equipment, for example.

Therefore, in order to ascertain the quality of agricultural defensive applications, it is necessary to evaluate the droplet spectrum. The objective of the present study was to assess the spectrum of drops produced in the aerial and terrestrial spraying of a pumpkin plantation, varying the spray nozzles and the composition of the application solution under different operating conditions, given there is little information available in literature regarding the use of phytosanitary products in this crop.

\section{Method}

The experiment was conducted at the Fazenda São José (São José Farm)-Aeroverde Group, located in the municipality of Aracruz (19 $49^{\prime} 11^{\prime \prime} \mathrm{S}$ and $40^{\circ} 16^{\prime} 27^{\prime \prime} \mathrm{W}$; at an altitude of $\left.100 \mathrm{~m}\right)$ in the State of Espírito Santo, Brazil. The laboratory analyses were carried out at the Laboratory of Mechanization and Application of Agricultural Defensives (LAMADA) of the Northern University Center of Espírito Santo, at the Federal University of Espírito Santo (CEUNES/UFES), in São Mateus-ES.

The assessments were carried out in two areas, irrigated by drip irrigation, corresponding to two applications: the first on July 1, 2013, in Area 1; and the second on August 6, 2013, in Area 2, both of approximately 8.0 ha. During the years prior to the survey, the areas underwent watermelon and bean cultivation. The purpose of evaluating two distinct areas was to verify if the results exhibited similar tendencies with respect to the studied characteristics (droplet spectra), under different field conditions (mainly environmental conditions), according to the methodology adapted from Bueno et al. (2011).

The employed cultivation system consisted of conventional planting, cultivated with hybrid pumpkins using a 100-day cycle. Planting was carried out on March 19, 2013, in Area 1, and on April 15, 2013, in Area 2, by mechanized sowing, with $2.0 \mathrm{~m} \times 2.0 \mathrm{~m}$ spacing and $0.02 \mathrm{~m}$ planting depths. All of the recommended cultural practices were carried out.

The experimental design was completely randomized, in a $6 \times 2$ factorial scheme, with five repetitions, composed of six forms of application and two solution compositions. The means of application corresponded to the combination of the 'type of spray' (aerial and terrestrial) and the 'application volume', as described in Table 1. 
Table 1. Description of the experimental treatments

\begin{tabular}{|c|c|}
\hline Description & Abbreviation \\
\hline $\begin{array}{l}\text { Terrestrial application using twin flat spray nozzles (AITTJ60-1102VP), } 200 \mathrm{kPa} \text { of pressure, } 150 \mathrm{~L} \mathrm{ha}^{-1} \text { of solution volume, } \\
\text { with and without adjuvant }\end{array}$ & T 150 IA \\
\hline $\begin{array}{l}\text { Terrestrial application using twin flat spray nozzles (AITTJ60-11025VP), } 500 \mathrm{kPa} \text { of pressure, } 300 \mathrm{~L} \mathrm{ha}^{-1} \text { of solution volume, } \\
\text { with and without adjuvant }\end{array}$ & T 300 IA \\
\hline $\begin{array}{l}\text { Terrestrial application using hollow cone spray nozzles (TX-VK10), } 300 \mathrm{kPa} \text { of pressure, } 150 \mathrm{~L} \mathrm{ha}^{-1} \text { of solution volume, with } \\
\text { and without adjuvant }\end{array}$ & $\mathrm{T} 150 \mathrm{~V}$ \\
\hline $\begin{array}{l}\text { Terrestrial application using hollow cone spray nozzles (TX-VK18), } 400 \mathrm{kPa} \text { of pressure, } 300 \mathrm{~L} \mathrm{ha}^{-1} \text { of solution volume, with } \\
\text { and without adjuvant }\end{array}$ & T $300 \mathrm{~V}$ \\
\hline $\begin{array}{l}\text { Aerial application using a Micronair AU500 rotating atomizer, } 200 \mathrm{kPa} \text { of pressure, } 12 \mathrm{~L} \mathrm{ha}^{-1} \text { of solution volume, with and } \\
\text { without adjuvant }\end{array}$ & A 12 \\
\hline $\begin{array}{l}\text { Aerial application using a Micronair AU500 rotating atomizer, } 200 \mathrm{kPa} \text { of pressure, } 25 \mathrm{~L} \mathrm{ha}^{-1} \text { of solution volume, with and } \\
\text { without adjuvant }\end{array}$ & A 25 \\
\hline
\end{tabular}

In the aerial applications, rotating screen atomizers were employed as a drop-breaking system, varying the position of the variable restriction unit (VRU) of the atomizer in order to obtain the assessed volumes.

The application solution was composed of water and water plus the adjuvant $(0.5 \% \mathrm{v} / \mathrm{v}$ Phosphatidylcholine and propionic acid $\left.\mathrm{Li} 700^{\circledR}\right)$. According to the manufacturer, the adjuvant is non-ionic, reduces surface tension, and is anti-drift.

In the terrestrial applications, a constant-pressure $\left(\mathrm{CO}_{2}\right)$ costal sprayer was employed, equipped with a bar containing six nozzles that were spaced apart by $0.50 \mathrm{~m}$, and $0.50 \mathrm{~m}$ in relation to the culture, retaining an average application velocity of $1.2 \mathrm{~m} \mathrm{~s}^{-1}$. The total area of the experimental units was $70.0 \mathrm{~m}^{2}(7.0 \mathrm{~m}$ wide and $10 \mathrm{~m}$ long), which were separated by a longitudinal distance of $10.0 \mathrm{~m}$. In order to avoid the border effect, two lines on each side of the plot and $1.0 \mathrm{~m}$ from each end were discarded.

During the aerial applications, an Ipanema 202-A agricultural aircraft, supplied with eight Micronair AU 5000 rotating screen atomizers, was utilized. The flight height was $3.0 \mathrm{~m}$ in relation to the culture, at an application speed of $180 \mathrm{~km} \mathrm{~h}^{-1}$, and the atomizer blades were placed at an angle of $45^{\circ}$. The size of the plots was $20,000 \mathrm{~m}^{2}$, corresponding to $250.0 \mathrm{~m}$ in length and $80.0 \mathrm{~m}$ in width, which is equivalent to five 16-meter times of the aircraft. Following application, a lateral distance of $50.0 \mathrm{~m}$ between each plot was established. The worked area corresponded to $2,000 \mathrm{~m}^{2}$, of which $15.0 \mathrm{~m}$ of each side and $100.0 \mathrm{~m}$ of each end were discarded.

The sprayings were carried out perpendicularly to the wind direction, and the environmental conditions of the two assays were distinct. The first application was carried out at a relative humidity of $70 \%$, air temperature of $26^{\circ} \mathrm{C}$, and wind velocity of $6.2 \mathrm{~km} \mathrm{~h}^{-1}$. In the second application, the average relative air humidity was $65 \%$; the air temperature was $25^{\circ} \mathrm{C}$, and the wind speed was of $7.9 \mathrm{~km} \mathrm{~h}^{-1}$. These data were obtained using a digital thermistor (Kestrel ${ }^{\circledR} 4000$ Pocket Weather Tracker).

The spectra of the spray droplets were evaluated by the analysis of the water-sensitive cards, which retained dimensions of $76 \mathrm{~mm} \times 26 \mathrm{~mm}$. Before spraying, four cards were randomly placed within the worked area of each plot, all suspended by a wooden rod above the plant canopy, positioned horizontally and directed upwards, without leaf interference.

Next, the card labels were packed in designated paper bags and separated according to the employed treatment. In the laboratory, they were scanned with 600 dpi non-interpolated resolution, in 24-bit color, and submitted to analysis using the e-Sprinkle ${ }^{\circledR}$ software, which is specific for droplet spectrum analyses.

The program emits a data sheet, from which the following parameters were studied: $D_{\mathrm{v} 0.5}$-droplet diameter, in which $50 \%$ of the volume of the sprayed liquid consists of droplets smaller than this value; NMD-numerical median diameter; RA-relative amplitude, and $\mathrm{Dv}<100 \mu \mathrm{m}$-percentage of the applied volume of which the droplets have less than $100 \mu \mathrm{m}$ in diameter.

Initially, the droplet spectra data were subjected to the Kolmogorov-smirnov normality and Levene variance homogeneity tests. Afterward, variance analysis (ANOVA) was performed, and, when a significant difference was verified, the means of the studied characteristics were compared using the Tukey test. The analyses were carried out with the aid of the R software (R Code, 2014).

\section{Results and Discussion}

When analyzing the $\mathrm{Dv}_{0.5}$ in the first application performed in Area 01, the interaction between the 'forms and volumes of application' and 'adjuvant' factors was not significant, indicating independence of the factors. 
Regarding the NMD variable, a significant interaction between the factors was observed, inferring dependence between them (Table 2).

Table 2. Volumetric median diameter $\left(\mathrm{Dv}_{0.5}\right)$ and numerical median diameter (NMD) of the sprayed droplets after the first aerial and terrestrial application onto the pumpkin culture, with and without adjuvant addition to the spray solution

\begin{tabular}{|c|c|c|c|c|c|c|}
\hline \multirow{3}{*}{$\begin{array}{l}\text { Forms and volumes } \\
\text { of application }\left(\mathrm{L} \mathrm{ha}^{-1}\right)\end{array}$} & \multicolumn{3}{|c|}{$\mathrm{Dv}_{0.5}(\mu \mathrm{m})$} & \multicolumn{3}{|c|}{ NMD $(\mu \mathrm{m})$} \\
\hline & \multicolumn{2}{|c|}{ Adjuvant } & \multirow{2}{*}{ Mean } & \multicolumn{2}{|c|}{ Adjuvant } & \multirow{2}{*}{ Mean } \\
\hline & Without & With & & Without & With & \\
\hline A 12 & 105 & 103 & $104 \mathrm{~A}$ & $80 \mathrm{Aa}$ & $78 \mathrm{Aa}$ & 79 \\
\hline A 25 & 136 & 109 & $123 \mathrm{~A}$ & $74 \mathrm{Aba}$ & $74 \mathrm{Aa}$ & 74 \\
\hline T $150 \mathrm{H}$ & 156 & 150 & $153 \mathrm{AB}$ & $100 \mathrm{ABCa}$ & $96 \mathrm{Aba}$ & 98 \\
\hline T $300 \mathrm{H}$ & 181 & 179 & $180 \mathrm{~B}$ & $94 \mathrm{ABCa}$ & $90 \mathrm{Aba}$ & 92 \\
\hline T $150 \mathrm{AI}$ & 444 & 440 & $442 \mathrm{C}$ & $109 \mathrm{Ca}$ & $143 \mathrm{Cb}$ & 126 \\
\hline T $300 \mathrm{AI}$ & 470 & 473 & $472 \mathrm{C}$ & $106 \mathrm{BCa}$ & $109 \mathrm{Ba}$ & 108 \\
\hline \multirow[t]{3}{*}{ Mean } & 249 & 242 & & 94 & 98 & \\
\hline & \multicolumn{3}{|c|}{$\mathrm{VC}=16.14 \%$} & \multicolumn{3}{|c|}{$\mathrm{VC}=13.21 \%$} \\
\hline & \multicolumn{3}{|c|}{$\mathrm{F}_{\mathrm{F}}=140.07 * * ; \mathrm{F}_{\mathrm{A}}=0.13^{\mathrm{ns}} ; \mathrm{F}_{\mathrm{FxA}}=0.21^{\mathrm{ns}}$} & \multicolumn{3}{|c|}{$\mathrm{F}_{\mathrm{F}}=26.09^{* *} ; \mathrm{F}_{\mathrm{A}}=2.14^{\mathrm{ns}} ; \mathrm{F}_{\mathrm{FxA}}=3.88^{\mathrm{n}}$} \\
\hline
\end{tabular}

Note. H: hollow cone spray nozzle; AI: air induction twin spray nozzle; $\mathrm{VC}$ : variation coefficient; $\mathrm{F}_{\mathrm{F}}$ : calculated $\mathrm{F}$ value regarding the 'form of application' factor; $\mathrm{F}_{\mathrm{A}}$ : calculated $\mathrm{F}$ value regarding the 'adjuvant' factor; $\mathrm{F}_{\mathrm{FxA}}$ : calculated $\mathrm{F}$ factor regarding the interaction between the 'form of application' and the 'adjuvant factors'.

Means followed by the same uppercased letter in a column, and lowercased letters in a row, do not differ between each other at a $5 \%$ level of significance by the Tukey test. ${ }^{* *}$ significant at 0.01 ; ${ }^{\text {ns }}$ not significant.

The aerial application treatments (12 and $\left.25 \mathrm{~L} \mathrm{ha}^{-1}\right)$ produced the lowest droplet sizes $\left(\mathrm{Dv}_{0.5}\right): 104$ and $123 \mu \mathrm{m}$, respectively; as well as the lowest NMD, which ranged from 74 to $79 \mu \mathrm{m}$. The highest values of $\mathrm{Dv}_{0.5}$ (442 and $472 \mu \mathrm{m})$ and NMD $(126$ and $108 \mu \mathrm{m})$ were produced by 150 and $300 \mathrm{~L} \mathrm{ha}^{-1}$ terrestrial applications, using air induction twin spray nozzles, as shown in Table 2.

The volumetric diameter of the droplets was not altered by the addition of the adjuvant. Also, it did not interfere with the NMD values, except the $150 \mathrm{~L} \mathrm{ha}^{-1}$ terrestrial application treatment with the air induction twin spray nozzle, in which the use of the adjuvant increased the NMD value.

Bueno et al. (2011) reported that the addition of the phosphatidylcholine + propionic acid adjuvant to the spray solution did not alter the $\mathrm{Dv}_{0.5}$ of the drops produced by the hollow cone spray nozzle. However, it caused a $30 \%$ reduction in the $\mathrm{Dv}_{0.5}$ of the droplets emitted by the flat air induction nozzle.

In a study determining the effect of formulations on spray characteristics, it was established that air induction nozzles are more susceptible to changes in the physical properties of the solution, and their behavior does not always follow that of conventional hydraulic nozzles (Mota \& Antuniassi, 2013).

The fact that some manufacturers do not provide information regarding droplet spectra can be a problem when working with air induction nozzles. According to Vitória et al. (2011), such information is essential for nozzle selection, in order to obtain greater efficiency in target coverage and lower environmental risks.

Regarding the RA and ' $<100$ ' variables, no significant interaction between the assessed factors was observed, indicating independence between them (Table 3). 
Table 3. Relative amplitude (RA) and percentage of the sprayed volume composed of droplets with diameters inferior to $100 \mu \mathrm{m}(<100)$ after the first aerial and terrestrial application onto the pumpkin culture, with and without adjuvant addition to the spray solution

\begin{tabular}{|c|c|c|c|c|c|c|}
\hline \multirow{3}{*}{$\begin{array}{l}\text { Forms and volumes } \\
\text { of application }\left(\mathrm{L} \mathrm{ha}^{-1}\right)\end{array}$} & \multicolumn{3}{|c|}{ RA } & \multicolumn{3}{|c|}{$<100$} \\
\hline & \multicolumn{2}{|c|}{ Adjuvant } & \multirow{2}{*}{ Mean } & \multicolumn{2}{|c|}{ Adjuvant } & \multirow{2}{*}{ Mean } \\
\hline & Without & With & & With & Without & \\
\hline A 12 & 0.843 & 0.803 & $0.823 \mathrm{~A}$ & 48.37 & 47.95 & $48.16 \mathrm{D}$ \\
\hline A 25 & 1.090 & 1.070 & $1.080 \mathrm{~B}$ & 24.79 & 35.73 & $30.26 \mathrm{C}$ \\
\hline T $150 \mathrm{H}$ & 0.930 & 1.003 & $0.967 \mathrm{AB}$ & 11.30 & 12.22 & $11.76 \mathrm{~B}$ \\
\hline T $300 \mathrm{H}$ & 1.200 & 1.161 & $1.181 \mathrm{~B}$ & 12.90 & 12.07 & $12.49 \mathrm{~B}$ \\
\hline T $150 \mathrm{AI}$ & 1.231 & 2.022 & $1.627 \mathrm{~B}$ & 1.57 & 0.73 & $1.15 \mathrm{~A}$ \\
\hline T $300 \mathrm{AI}$ & 1.221 & 1.082 & 1.152B & 1.70 & 1.56 & $1.63 \mathrm{~A}$ \\
\hline \multirow[t]{3}{*}{ Mean } & 1.086 & 1.190 & & 16.77 & 18.38 & \\
\hline & \multicolumn{3}{|c|}{$\mathrm{VC}=17.77 \%$} & \multicolumn{3}{|c|}{$\mathrm{VC}=28.40 \%$} \\
\hline & \multicolumn{3}{|c|}{$\mathrm{F}_{\mathrm{F}}=5.05^{* *} ; \mathrm{F}_{\mathrm{A}}=2.12^{\mathrm{ns}} ; \mathrm{F}_{\mathrm{FxA}}=0.93^{\mathrm{ns}}$} & \multicolumn{3}{|c|}{$\mathrm{F}_{\mathrm{F}}=90.32^{* *} ; \mathrm{F}_{\mathrm{A}}=1.09^{\mathrm{ns}} ; \mathrm{F}_{\mathrm{FxA}}=1.80^{\mathrm{n}}$} \\
\hline
\end{tabular}

Note. $\mathrm{H}$ : hollow cone spray nozzle; $\mathrm{AI}$ : air induction twin spray nozzle; $\mathrm{VC}$ : variation coefficient; $\mathrm{F}_{\mathrm{F}}$ : calculated $\mathrm{F}$ value regarding the 'form of application' factor; $\mathrm{F}_{\mathrm{A}}$ : calculated $\mathrm{F}$ value regarding the 'adjuvant' factor; $\mathrm{F}_{\mathrm{FxA}}$ : calculated $\mathrm{F}$ factor regarding the interaction between the 'form of application' and the 'adjuvant factors'.

Means followed by the same uppercased letter in a column, and lowercased letters in a row, do not differ between each other at a $5 \%$ level of significance by the Tukey test. ${ }^{* *}$ significant at $0.01 ;{ }^{\text {ns }}$ not significant.

The droplet set uniformity, or the droplet size variation spectrum, can be expressed by the RA, in which the higher the RA value, the larger the spray droplet size range. According to Viana et al. (2010), the homogeneous droplet spectrum retains a relative amplitude value that tends to zero. The results of the present study indicate that the lowest RA was verified in the aerial treatment using a solution volume of $12 \mathrm{~L} \mathrm{ha}^{-1}(0.823)$, and in the terrestrial treatment, with $150 \mathrm{~L} \mathrm{ha}^{-1}$ of solution (0.967), using hollow cone spray nozzles, inferring greater homogeneity in droplet formation when compared to the venturi system of hydraulic air induction twin spray nozzles.

Silva (2009) evaluated the uniformity of the set of droplets produced by aerial systems (hydraulic nozzles, rotating disc atomizers, and electrostatic systems), and also verified the lowest relative amplitude values with the use of atomizers $\left(15 \mathrm{~L} \mathrm{ha}^{-1}\right)$ and the electrostatic system $\left(5 \mathrm{~L} \mathrm{ha}^{-1}\right)$ in the canopy of a rice culture. The use of high-speed rotating atomizers in agricultural aviation generates a more uniform droplet spectrum (Schröder, 2006), corroborating with the results described in the present study.

According to Cunha et al. (2003), the estimation of the drift potential of a spray can be evaluated by the percentage of droplets with diameters smaller than $100 \mu \mathrm{m}$. There is no standard value indicative of drift risk or safe application. Nevertheless, according to the same authors, volume values below $15 \%$ of droplets with diameters smaller than $100 \mu \mathrm{m}$ are generally better suited for environmentally safe applications.

Therefore, aerial applications with the described droplet spectrum should be carried out under environmental conditions that are favorable for phytosanitary applications in order to reduce drift losses to a minimum, such as air temperatures lower than $30^{\circ} \mathrm{C}$, relative humidity higher than $55 \%$, and wind speeds less than $12 \mathrm{~km} \mathrm{~h}^{-1}$.

The air induction nozzles can reduce potential drift risks. However, the formation of thick and very thick droplets is possible, resulting in increased drainage of the solution and, consequently, reduced spray efficiency (Lesnik et al., 2005). Furthermore, according to Heinkel et al. (2000) and Vitória and Leite (2014), the use of air induction nozzles can provide a similar performance to that of conventional spraying (with single flat spray nozzles), as long as the spray operator receives information regarding how to initially select the nozzle and how to improve its performance.

No significant difference between the presence and absence of the adjuvant in the spray solution was observed regarding relative amplitude values and the percentage of droplets smaller than $100 \mu \mathrm{m}$. A laboratory study carried out employing TT 11002 and TTI 11002 nozzles, with the addition of the phosphatidylcholine + propionic acid adjuvant to the spray liquid, also showed no alteration in relative amplitude values (Cunha et al., 2010).

In the second application (Area 2), the interaction between the 'forms and volumes of application' and 'adjuvant' factors was not significant, regarding both the $\mathrm{DV}_{0.5}$ and the NMD parameters. With respect to the two variables, 
smaller droplet sizes were obtained when using the rotating atomizers with volumes of 12 and $25 \mathrm{~L} \mathrm{ha}^{-1}$ of solution. In contrast, the highest droplet size values were produced when using the air induction twin spray nozzles, with volumes of 150 and $300 \mathrm{~L} \mathrm{ha}^{-1}$ of solution (Table 4).

Table 4. Volumetric median diameter $\left(\mathrm{Dv}_{0.5}\right)$ and numeric median diameter (NMD) of the sprayed droplets after the second aerial and terrestrial application onto the pumpkin culture, with and without adjuvant addition to the spray solution

\begin{tabular}{|c|c|c|c|c|c|c|}
\hline \multirow{3}{*}{$\begin{array}{l}\text { Forms and volumes } \\
\text { of application }\left(\mathrm{L} \mathrm{ha}^{-1}\right)\end{array}$} & \multicolumn{3}{|c|}{$\mathrm{Dv}_{0.5}(\mu \mathrm{m})$} & \multicolumn{3}{|c|}{ NMD $(\mu \mathrm{m})$} \\
\hline & \multicolumn{2}{|c|}{ Adjuvant } & \multirow{2}{*}{ Mean } & \multicolumn{2}{|c|}{ Adjuvant } & \multirow{2}{*}{ Mean } \\
\hline & Without & With & & With & Without & \\
\hline A 12 & 108 & 96 & $102 \mathrm{~A}$ & 70 & 60 & $65 \mathrm{~A}$ \\
\hline A 25 & 120 & 121 & $121 \mathrm{AB}$ & 85 & 74 & $80 \mathrm{~A}$ \\
\hline T $150 \mathrm{H}$ & 165 & 174 & $170 \mathrm{BC}$ & 106 & 100 & $103 \mathrm{~B}$ \\
\hline T $300 \mathrm{H}$ & 171 & 200 & $186 \mathrm{C}$ & 100 & 103 & $102 \mathrm{~B}$ \\
\hline T $150 \mathrm{AI}$ & 440 & 433 & $437 \mathrm{D}$ & 121 & 125 & $123 \mathrm{C}$ \\
\hline T $300 \mathrm{AI}$ & 418 & 421 & $420 \mathrm{D}$ & 106 & 96 & $101 \mathrm{~B}$ \\
\hline \multirow[t]{2}{*}{ Mean } & 237 & 241 & & 98 & 93 & \\
\hline & \multicolumn{3}{|c|}{$\mathrm{VC}=12.40 \%$} & \multicolumn{3}{|c|}{$\mathrm{VC}=13.23 \%$} \\
\hline
\end{tabular}

Note. $\mathrm{H}$ : hollow cone spray nozzle; AI: air induction twin spray nozzle; $\mathrm{VC}$ : variation coefficient; $\mathrm{F}_{\mathrm{F}}$ : calculated $\mathrm{F}$ value regarding the 'form of application' factor; $\mathrm{F}_{\mathrm{A}}$ : calculated $\mathrm{F}$ value regarding the 'adjuvant' factor; $\mathrm{F}_{\mathrm{FxA}}$ : calculated $\mathrm{F}$ factor regarding the interaction between the 'form of application' and the 'adjuvant factors'.

Means followed by the same uppercased letter in a column, and lowercased letters in a row, do not differ between each other at a $5 \%$ level of significance by the Tukey test. ${ }^{* *}$ significant at $0.01{ }^{\text {ns }}$ not significant.

When evaluating droplet sizes using single, low-drift, and hydraulic air induction flat spray nozzles, with the same nominal flow rate, Nuyttens et al. $(2007,2009)$ also reported that the air induction nozzles produced larger droplet sizes and retained lower propensity to drift, which corroborates with the results obtained in the present study.

Adjuvants with surfactant properties, such as phosphatidylcholine + propionic acid, have the ability to reduce the surface tension of aqueous solutions applied to a crop, improving leaf adherence (Bargel et al., 2006). This property can lead to a decrease in droplet size; however, the magnitude of this process is not large and varies according to the employed nozzle (Butler-Ellis et al., 2001). This fact may explain the non-alteration of the volumetric and numerical median diameters with the addition of the adjuvant to the spray solution, observed in the present study.

Regarding the RA and the ' $<100$ ' variables, no significant interaction between the assessed factors was observed, suggesting independence between them. The lowest RA (0.689) was described in the aerial application with $12 \mathrm{~L} \mathrm{ha}^{-1}$, indicating optimal droplet production uniformity, differing from all other treatments (Table 5). 
Table 5. Relative amplitude (RA) and percentage of the sprayed volume composed of droplets with diameters inferior to $100 \mu \mathrm{m}(<100)$ after the second aerial and terrestrial application onto the pumpkin culture, with and without adjuvant addition to the spray solution

\begin{tabular}{|c|c|c|c|c|c|c|}
\hline \multirow{3}{*}{$\begin{array}{l}\text { Forms and volumes } \\
\text { of application }\left(\mathrm{L} \mathrm{ha}^{-1}\right)\end{array}$} & \multicolumn{3}{|c|}{ RA } & \multicolumn{3}{|c|}{$<100$} \\
\hline & \multicolumn{2}{|c|}{ Adjuvant } & \multirow{2}{*}{ Mean } & \multicolumn{2}{|c|}{ Adjuvant } & \multirow{2}{*}{ Mean } \\
\hline & Without & With & & With & Without & \\
\hline A 12 & 0.777 & 0.601 & $0.689 \mathrm{~A}$ & 43.70 & 62.40 & $53.05 \mathrm{C}$ \\
\hline A 25 & 1.045 & 1.088 & $1.067 \mathrm{~B}$ & 28.60 & 36.61 & $32.61 \mathrm{~B}$ \\
\hline Т $150 \mathrm{H}$ & 1.098 & 1.044 & $1.071 \mathrm{~B}$ & 12.21 & 11.80 & $12.01 \mathrm{~A}$ \\
\hline T $300 \mathrm{H}$ & 1.222 & 1.111 & $1.167 \mathrm{~B}$ & 10.66 & 7.78 & $9.22 \mathrm{~A}$ \\
\hline T $150 \mathrm{AI}$ & 1.256 & 1.321 & $1.289 \mathrm{~B}$ & 1.61 & 1.70 & $1.66 \mathrm{~A}$ \\
\hline T $300 \mathrm{AI}$ & 1.138 & 1.173 & $1.156 \mathrm{~B}$ & 2.25 & 3.23 & $2.74 \mathrm{~A}$ \\
\hline \multirow[t]{3}{*}{ Mean } & 1.089 & 1.056 & & 16.51 & 20.59 & \\
\hline & \multicolumn{3}{|c|}{$\mathrm{VC}=17.00 \%$} & \multicolumn{3}{|c|}{$\mathrm{VC}=34.43 \%$} \\
\hline & \multicolumn{3}{|c|}{$\mathrm{F}_{\mathrm{F}}=9.01^{* *} ; \mathrm{F}_{\mathrm{A}}=0.07^{\mathrm{ns}} ; \mathrm{F}_{\mathrm{FxA}}=0.30^{\mathrm{ns}}$} & \multicolumn{3}{|c|}{$\mathrm{F}_{\mathrm{F}}=66.70^{* *} ; \mathrm{F}_{\mathrm{A}}=3.81^{\mathrm{ns}} ; \mathrm{F}_{\mathrm{FxA}}=1.90^{\mathrm{ns}}$} \\
\hline
\end{tabular}

Note. H: hollow cone spray nozzle; AI: air induction twin spray nozzle; $\mathrm{VC}$ : variation coefficient; $\mathrm{F}_{\mathrm{F}}$ : calculated $\mathrm{F}$ value regarding the 'form of application' factor; $\mathrm{F}_{\mathrm{A}}$ : calculated $\mathrm{F}$ value regarding the 'adjuvant' factor; $\mathrm{F}_{\mathrm{FxA}}$ : calculated $\mathrm{F}$ factor regarding the interaction between the 'form of application' and the 'adjuvant factors'.

Means followed by the same uppercased letter in a column, and lowercased letters in a row, do not differ between each other at a $5 \%$ level of significance by the Tukey test. ${ }^{*}$ significant at $0.01 ;{ }^{\text {ns }}$ not significant.

Regarding the nozzles that operate with hydraulic pressure, the production of significantly uneven drops has been described, which hampers adequate target coverage. The development of technologies that produce more uniform drops is required in order to reduce the number of extremely small or large droplets (Vitória \& Leite, 2014). The adoption of spray equipment that employs rotating atomizers as a drop-breaking system is an option.

The aerial application using $12 \mathrm{~L} \mathrm{ha}^{-1}$ exhibited the largest percentage of spray droplets smaller than $100 \mu \mathrm{m}$, equivalent to $53.05 \%$, differing from the other treatments. This type of droplet spectrum is highly susceptible to drift risk. It is noteworthy that, according to necessity, one can increase the size of the generated droplets by simply changing the angle of the rotating atomizer blades. There are also commercial rotating atomizers that contain specific devices to increase droplet size.

The use of the adjuvant did not significantly interfere with the relative amplitude values and the percentage of droplets smaller than $100 \mu \mathrm{m}$. Most of the adjuvants that retain spreader functions, found on the market, have surface tension-reducing properties in their composition, which alter the droplet size. However, the magnitude of this process is not very large and varies according to the employed spraying system.

According to Lan et al. (2007), the addition of adjuvants can alter application performance. Therefore, the origin of these products and the implications of their use must be known before acquisition and use.

\section{Conclusion}

Rotating atomizers provide larger droplet sizes, while when using air induction twin spray nozzle, the sizes are smaller.

The diameter of the volumetric median, the relative amplitude, and the percentage of droplets smaller than 100 $\mu \mathrm{m}$ are not altered by adjuvant addition to the spray solution.

The pressure regulation and the two solution volumes (12 and $\left.25 \mathrm{~L} \mathrm{ha}^{-1}\right)$, employed in the aerial application, produced the lowest relative amplitude of the droplet spectrum. However, both volumes resulted in a higher percentage of droplets that were susceptible to drift risk (smaller than $100 \mu \mathrm{m}$ ), when subjected to the adopted pressure.

\section{References}

Bargel, H., Koch, K., Cerman, Z., \& Neinhuis, C. (2006). Structure-function relationships of the plant cuticle and cuticular waxes-A smart material? Functional Plant Biology, 33(10), 893-910. https://doi.org/ 10.1071/FP06139 
Bayer, T., Costa, I. F., Lenz, G., Zemolin, C., Marques, L. N., \& Stefanelo, M. S. (2011). Equipamentos de pulverização aérea e taxas de aplicação de fungicida na cultura do arroz irrigado. Revista Brasileira de Engenharia Agrícola e Ambiental, 15(1), 192-198. https://doi.org/10.1590/S1415-43662011000200007

Bouse, L. F., Carlton, J. B., Kirk, I. W., \& Hirsch Júnior, T. J. (1994). Nozzle selection for optimizing deposition and minimizing spray drift for the Air tractor. Transactions of the ASAE, 37(6), 1725-1731. https://doi.org/ $10.13031 / 2013.28259$

Bueno, M. R., Cunha, J. P. A. R., \& Alves, G. S. (2011). Estudo do espectro de gotas produzidas nas pulverizações aérea e terrestre na cultura da batata. Ciências Agrárias Magazine, 54(3), 225-234. https://doi.org/10.4322/rca.2012.018

Butler-Ellis, M. C., Tuck, C. R., \& Miller, P. C. H. (2001). How surface tension of surfactant solutions influences the characteristics of sprays produced by hydraulic nozzles used for pesticide application. Colloids and Surfaces A: Physicochemical and Engineering Aspects, 180(3), 267-276. https://doi.org/ 10.1016/S0927-7757(00)00776-7

Carvalho, S. J. P. D., Damin, V., Dias, A. C. R., Yamasaki, G. M., \& Christoffoleti, P. J. (2009). Eficácia e pH de caldas de glifosato após a adição de fertilizantes nitrogenados e utilização de pulverizador pressurizado por $\mathrm{CO}_{2}$. Pesquisa Agropecuária Brasileira, 44(6), 569-575. https://doi.org/10.1590/S0100-204X2009 000600004

Chechetto, R. G., Antuniassi, U. R., Mota, A. A. B., Carvalho, F. K., Arruda, A. C., \& Vilela, C. M. (2013). Influência de pontas de pulverização e adjuvantes no potencial de redução de deriva em túnel de vento. Semina: Ciências Agrárias, 34(1), 37-46. https://doi.org/10.5433/1679-0359.2013v34n1p37

Cunha, J. P. A. R., Teixeira, M. M., Coury, J. R., \& Ferreira, L. R. (2003). Avaliação de estratégias para redução da deriva de agrotóxicos em pulverizações hidráulicas. Planta Daninha, 21(2), 325-332. https://doi.org/ $10.1590 / \mathrm{S} 0100-83582003000200019$

Cunha, J. P. A. R., Teixeira, M. M., \& Fernandes, H. C. (2007). Avaliação do espectro de gotas de pontas de pulverização hidráulicas utilizando a técnica da difração do raio laser. Engenharia Agrícola, 27(1), 10-15. https://doi.org/10.1590/S0100-69162007000200002

Cunha, J. P. A. R., \& Alves, G. S. (2009). Características físico-químicas de soluções aquosas com adjuvantes de uso agrícola. Interciência, 34(9), 655-659.

Cunha, J. P. A. R., Bueno, M. R., \& Ferreira, M. C. (2010). Espectro de gotas de pontas de pulverização com adjuvantes de uso agrícola. Planta Daninha, 28(1), 1153-1158. https://doi.org/10.1590/S0100-83582010 000500023

Cunha, J. P. A. R., Silva, L. L., Boller, W., \& Rodrigues, J. F. (2010). Aplicação aérea e terrestre de fungicida para o controle de doenças do milho. Revista Ciência Agronômica, 4(3), 366-372. https://doi.org/10.1590/ S1806-66902010000300007

Figueiredo, J. L. A., Teixeira, M. M., Picanço, M. C., Pinto, F. A. C., \& Prat, M. H. (2007). Avaliação da uniformidade de aplicação e do espectro de gotas de bicos hidráulicos. Revista Ciências Técnicas Agropecuárias, 16(3), 47-52.

Heinkel, R., Fried, A., \& Lange, E. (2000). The effect of air injector nozzles on crop penetration and biological performance of fruit sprayers. Aspects of Applied Biology, 57(1), 301-307.

Lan, Y., Hoffmann, W. C., Fritz, B. K., Martins, D. E., \& Lopez, L. E. (2007). Drift reduction with drift control adjuvants (p. 14). Sant Joseph: ASABE-Annual International Meeting.

Lesnik, M., Pintar, C., Lobnik, A., \& Kolar, M. (2005). Comparison of the effectiveness of standard and drift-reducing nozzles for control of some pests of apple. Crop Protection, 24(2), 93-100. https://doi.org/ 10.1016/j.cropro.2004.06.011

Mota, A. A. B., \& Antuniassi, U. (2013). Influência de adjuvantes no espectro de gotas de ponta com indução de ar. Energia na Agricultura, 28(1), 01-05. https://doi.org/10.17224/EnergAgric.2013v28n1p01-05

Nuyttens, D., Baetens, K., Schampheleire, M., \& Sonck, B. (2007). Effect of nozzle type, size and pressure on spray droplet characteristics. Biosystems Engineering, 97(3), 333-345. https://doi.org/10.1016/j.biosystem seng.2007.03.001 
Nuyttens, D., De Schampheleire, M., Verboven, P., Brusselman, E., \& Dekeyser, D. (2009). Droplet size and velocity characteristics of agricultural sprays. Transactions of the ASABE, 52(5), 1471-1480. https://doi.org/ $10.13031 / 2013.29127$

Silva, T. M. B. (2009). Tecnologia de aplicação aérea de fungicidas na cultura do arroz irrigado (Dissertation Masters in Agronomy, Center of Rural Sciences, Federal University of Santa Maria, Santa Maria, RS, Brazil).

Schröder, E. P. (2006). Pulverização: Em alta rotação. Terra Aviação.

Van Zyl, S. A., Brink, J., Calitz, F. J., Coertze, S., \& Fourie, P. H. (2010). The use of adjuvants to improve spray deposition and Botrytis cinerea control on Chardonnay grapevine leaves. Crop Protection, 29(1), 58-67. https://doi.org/10.1016/j.cropro.2009.08.012

Viana, R. G., Ferreira, L. R., Ferreira, M. C., Teixeira, M. M., Rosell, J. R., Tuffi Santos, L. D., \& Machado, A. F. L. (2010). Distribuição volumétrica e espectro de gotas de pontas de pulverização de baixa deriva. Planta Daninha, 28(2), 439-446. https://doi.org/10.1590/S0100-83582010000200024

Vitória, E. L., Teixeira, M. M., \& Ruas, R. A. A. (2011). Coeficiente de assimetria de pearson como parâmetro de avaliação da uniformidade de distribuição de líquido das pontas de pulverização hidráulicos de jato plano. Enciclopédia Biosfera, 7(13), 222-229. https://doi.org/10.5327/Z\%201982-8470201400031831

Vitória, E. L., \& Leite, J. U. Q. (2014). Espectro de gotas de pontas de pulverização de jato cônico vazio. Enciclopédia Biosfera, 10(18), 1551-1559.

\section{Copyrights}

Copyright for this article is retained by the author(s), with first publication rights granted to the journal.

This is an open-access article distributed under the terms and conditions of the Creative Commons Attribution license (http://creativecommons.org/licenses/by/4.0/). 